\title{
Tissue Distribution of Polybrominated Diphenyl Ethers (PBDEs) in Captive Domestic Pigs, Sus scrofa, from a Village Near an Electronic Waste Recycling Site in South China
}

\author{
Y. F. Li • Z. Z. Yang $\cdot$ C. H. Wang . \\ Z. J. Yang $\cdot$ Z. F. Qin · S. Fu
}

Received: 17 July 2009/ Accepted: 8 December 2009/Published online: 20 December 2009

(C) Springer Science+Business Media, LLC 2009

\begin{abstract}
The dominant part of PBDEs residue in pig tissues was BDE-47 accounted for $48.2 \% \sim 66.9 \%$, followed by BDE-99 from $15.9 \%$ to $24.2 \%$. When the data were on lipid weight basis, the $\sum$ PBDEs concentrations in tissues of individual pig showed the same order of liver $>$ muscle, intestine $>$ fat. Principal component analysis and PBDE congener mean concentration ratios of muscle versus liver $(\mathrm{M} / \mathrm{L})$, fat versus liver $(\mathrm{F} / \mathrm{L})$ and intestine versus liver (I/L) showed the higher accumulation ability of PBDEs in liver than in other tissues. And the PBDE mean concentration ratios of M/L, F/L and $\mathrm{I} / \mathrm{L}$ had the trend of decrease with increasing bromination degree of PBDE congeners.
\end{abstract}

Keywords Polybrominated diphenyl ethers (PBDEs) · Pig · Tissue · Electronic waste

\section{Y. F. Li}

College of Chemistry and Chemical Engineering,

Henan Institute of Science and Technology,

453003 Xinxiang, Henan, China

\section{Z. Z. Yang $(\varangle) \cdot$ C. H. Wang}

Xinxiang Medical College, 453003 Xinxiang,

Henan, China

e-mail: yzz4321@126.com

\section{Z. Z. Yang · Z. F. Qin · S. Fu}

State Key Laboratory of Environmental Chemistry and Ecotoxicology, Research Center for Eco-Environmental

Sciences, Chinese Academy of Sciences,

Post Office Box 2871, 18 Shuangqing Road,

100085 Haidian District, Beijing, China

\section{Z. J. Yang}

Nanyang Hongyu Machine and Electricity Ltd.,

474675 Nanzhao, Henan, China
Polybrominated diphenyl ethers (PBDEs) are man-made chemicals widely used as flame retardants in a wide variety of plastics, textiles, electronic components, etc. PBDEs have been manufactured as three formulations: PentaBDE composed mainly of tri- to hexa-BDEs, OctaBDE composed mainly of hexa- to octa-BDEs, and DecaBDE composed mainly of BDE-209. Due to their lipophilicity, persistence, bioaccumulation and potential toxicity such as thyroidogenic, estrogenic, and hepatic effects as well as neurodevelopmental disorders resulted from prolonged exposure to PBDEs (Darnerud et al. 2001), the PentaBDE and OctaBDE formulations were banned from all uses in Europe in 2004, and were voluntarily taken out of production in North America at the end of 2004. DecaBDE remains in use and had a market demand of 56,100 metric tons in 2001(Law et al. 2006).

As these PBDEs are not permanently bound to the polymer matrix, they leach out during natural operational life as well as during processing, recycling or combustion of the polymeric material (D'Silva et al. 2004). With increasing contamination in environment matrixes (Hites 2004), there is increasing concern for the bioavailability and degradation of PBDEs in biota (Huwe and Smith 2007). As the concerning of human health, soil, dust indoor, food, human milk and blood ( $\mathrm{Li}$ et al. 2008; Toms et al. 2008; Ohta et al. 2002; Bi et al. 2006) was monitored to estimated the contaminated load in human body. For the reason of pally relationship with human, pet cats (Dye et al. 2007) were used as sentinels. But in the country of China, the domestic animals might be better applied as sentinels for their widely feeding and tending to reside in a smallscale area. Especially, the domestic animals are the main meat sources of the dwellers in the country of China. In the present work, we chose the captive domestic pigs (Sus scrofa) from a village near an electronic waste recycling 
site in South China to investigate the contamination level and tissue distribution of PBDEs in them. We aimed the congener profile and concentration difference of PBDEs in tissues of captive domestic pigs which had similar food source and living surroundings with the dwellers.

\section{Materials and Methods}

PBDE analytical standard method 1614 native PAR stock solution EO-5278 (unlabeled BDE-28, 47, 99, 100, 153, $154,183,209)$, method 1614 labeled surrogate stock solution EO-5277 $\left({ }^{13} \mathrm{C}_{12}\right.$ labeled BDE-28, 47, 99, 100, 153, $154,183,209)$ and method 1614 labeled injection internal stock solution EO-5275 $\left({ }^{13} \mathrm{C}_{12}\right.$ labeled CB-52, 138) was purchased from Cambridge Isotope Laboratories, Inc. (Andover, MA). Hexane and dichloromethane used for the extraction and cleanup procedures were pesticide grade (J. T. Baker, USA), and other solvents and reagents were of analytical grade.

Three captive pigs, named A (1 year, about $100 \mathrm{~kg}$ ), B (1 year, about $150 \mathrm{~kg}$ ) and C (1 year, about $150 \mathrm{~kg}$ ), were chose to sample the muscle, fat, liver and small intestine, which were expressed as -M, -F, -L and -I, respectively, when those pigs were butchered in Nov. 2006. After been homogenized in a tissue homogenizer, $0.5 \sim 8 \mathrm{~g}$ of various tissues were freeze-dried, and then they were preserved frozen at $-20^{\circ} \mathrm{C}$ until analysis.

Eight PBDE congeners (BDE-28, 47, 99, 100, 153, 154, 183 , 209) were detected in samples using ${ }^{13} \mathrm{C}_{12}$ isotope dilution methods which was described below. Dried tissue samples were ground with anhydrous sodium sulfate into free-flowing powder, respectively. The samples were extracted with $200 \mathrm{~mL}$ of hexane/dichloromethane (1:1, $\mathrm{v} / \mathrm{v}$ ) in Soxhlet extraction mode for $24 \mathrm{~h}$. An aliquot of the extract was used for gravimetric lipid determination. All samples were spiked with eight ${ }^{13} \mathrm{C}_{12}$ labeled PBDE recovery standards (EO-5277) prior to extraction and cleanup. Then the concentrated extracts were cleaned on a column (15-mm i.d.) packed, from the bottom to top, with $1 \mathrm{~g}$ activated silica gel, $3 \mathrm{~g}$ basic silica gel (EPA Method 1614, Sect. 7.5.1.3), $1 \mathrm{~g}$ activated silica gel, $4 \mathrm{~g}$ acid silica gel (44\% concentrated sulfuric acid, w/w), $4 \mathrm{~g}$ acid silica gel $(22 \%$ concentrated sulfuric acid, w/w), $1 \mathrm{~g}$ activated silica gel and $1 \mathrm{~cm}$ anhydrous sodium sulfate. After eluted with $100 \mathrm{~mL}$ of hexane, the concentrated elution was loaded on another column (8-mm i.d.) containing $2 \mathrm{~g}$ silver nitrate $\left(\mathrm{AgNO}_{3}\right)$ silica $(10 \%$, w/w), $2 \mathrm{~g}$ activated silica gel and $1 \mathrm{~cm}$ anhydrous sodium sulfate. PBDEs were separated from PCBs by two elutions: $40 \mathrm{ml}$ hexane for PCBs and $40 \mathrm{ml}$ hexane/dichloromethane $(1: 1, \mathrm{v} / \mathrm{v})$ for PBDEs. The PBDEs fractions were collected and reduced to $30 \mu \mathrm{l}$ under a gentle $\mathrm{N} 2$ stream. Then, ${ }^{13} \mathrm{C}_{12}$ labeled injection internal standards (EO-5275) were added prior to the GC injection. Throughout the extraction, cleanup and analysis procedure, the analytes were protected from light by wrapping the containers with aluminum foil or by using amber glassware.

The samples were analyzed on an Agilent 6,890 series gas chromatograph coupled with an Agilent 5,973 mass spectrometer. For the analysis of BDE-28, 47, 99, 100, 153, 154,183 , the mass spectrometer was operated with electron impact ionization (EI) source in the selected ion monitoring (SIM) mode and a DB-5MS $(30 \mathrm{~m} \times 0.25 \mathrm{~mm}$ i.d., $0.25 \mu \mathrm{m}$ film thickness) capillary column was used. The monitored ion (m/z) 405.8/407.8, 483.7/485.7, 403.8/405.8, 403.8/405.8, 481.7/483.7, 481.7/483.7 and 561.6/563.6 were selected for unlabled BDE-28, 47, 99, 100, 153, 154 and 183, respectively. And 417.8/419.8, 495.7/497.7, 415.8/417.8, 415.8/417.8, 493.7/495.7, 493.7/495.7 and 573.6/575.6 for ${ }^{13} \mathrm{C}_{12}$ labeled BDE-28, 47, 99, 100, 153, 154 and 183, respectively. The temperature of the MS ion source (electron energy $70 \mathrm{eV}$ ) and transfer line were kept at 230 and $300^{\circ} \mathrm{C}$, respectively. The $\mathrm{GC}$ oven temperature program was carried out as follows: initial temperature $100^{\circ} \mathrm{C}$ held for $1 \mathrm{~min}$, increased to $150^{\circ} \mathrm{C}$ at $10^{\circ} \mathrm{C} / \mathrm{min}$ held $5 \mathrm{~min}$, and then to $280^{\circ} \mathrm{C}$ at $5^{\circ} \mathrm{C} / \mathrm{min}$, to $290^{\circ} \mathrm{C}$ at $10^{\circ} \mathrm{C} /$ $\mathrm{min}$, held for $15 \mathrm{~min}$. Helium was used as the carrier gas at a flow rate of $1 \mathrm{ml} / \mathrm{min}$. For the determination of BDE-209, the mass spectrometer was operated with negative chemical ionization (NCI) in SIM mode and a DB-5 MS $(15 \mathrm{~m} \times 0.25 \mathrm{~mm}$ i.d., $0.25 \mu \mathrm{m}$ film thickness) capillary column was used. The monitored ion $(\mathrm{m} / \mathrm{z})$ 484.7/486.7 and 494.7/496.7 were selected for unlabled and ${ }^{13} \mathrm{C}_{12}$ labeled BDE-209 respectively. Methane was used as a chemical ionization moderating gas and helium as the carrier gas at a flow rate of $1.5 \mathrm{ml} / \mathrm{min}$. The ion source and interface temperatures were set to 150 and $300^{\circ} \mathrm{C}$, respectively. The temperature program was from $80^{\circ} \mathrm{C}$ $\left(1 \mathrm{~min}\right.$ ) to $200^{\circ} \mathrm{C}$ at $10^{\circ} \mathrm{C} / \mathrm{min}$, and to $300^{\circ} \mathrm{C}$ (held $15 \mathrm{~min}$ ) at $20^{\circ} \mathrm{C} / \mathrm{min}$. Both experiments were used the splitless injection mode and injected $1 \mu \mathrm{l}$ (injector temperature $265^{\circ} \mathrm{C}$ ) with a solvent delay set at $6 \mathrm{~min}$.

Quality control was done by regular analyses of procedural blanks, and regular injection of solvent blanks and standards. The residue concentrations in samples below quantificational limits were regarded to be equal to zero in calculation of sum, means and so on. The limit of quantifications (LOQ) defined as the mean value of corn oil matrix procedural blanks (spiked with eight ${ }^{13} \mathrm{C}_{12}$ labeled PBDE recovery standards) plus a safety margin of $3 \times$ standard deviation $(\mathrm{SD})$ of the procedural blanks were $0.005 \sim 0.03 \mathrm{ng} / \mathrm{g}$ lipid weight for BDE-28, 47, 99, 100, 153, 154 and 183 in EI-MS mode, and $0.04 \mathrm{ng} / \mathrm{g}$ lipid weight for deca-BDE in NCI-MS mode. The recovery rates of ${ }^{13} \mathrm{C}_{12}$ labeled BDE-209 spiked to tissue samples ranged 
from $60 \%$ to $90 \%$, and for the other ${ }^{13} \mathrm{C}_{12}$ labeled PBDEs, it were $75 \% \sim 110 \%$.

\section{Results and Discussion}

As illustrated in Fig. 1, all 8 target PBDE congeners were consistently found in tissues of pigs. The dominant part of PBDEs residue in tissues was BDE-47 accounted for $48.2 \% \sim 66.9 \%$, followed by BDE-99 from $15.9 \%$ to $24.2 \%$. When the data were on lipid weight basis, the $\sum$ PBDEs (sum of the BDE-28, 47, 99, 100, 153, 154, 183, 209) concentrations in tissues of individual pig showed the same order of liver $>$ muscle, intestine $>$ fat. The $\sum$ PBDEs in livers ranged from 54.2 to $60.6 \mathrm{ng} / \mathrm{g}$ lipid weight, and in fats ranged from 20.2 to $28.9 \mathrm{ng} / \mathrm{g}$ lipid weight. Compared with other studies, as the village had undertaken e-waste recycling for years, the pig tissues PBDEs level of this study was much higher than the market-based samples (Huwe and Larsen 2005) but lower than the free-range fowls from another e-waste recycling site in Guangdong Province of China (Luo et al. 2009).

Principal component analysis (PCA) was performed to evaluate similarities or differences between the PBDE congener patterns of each samples, all data were normalized to a percent of the sum of PBDEs. PCs were
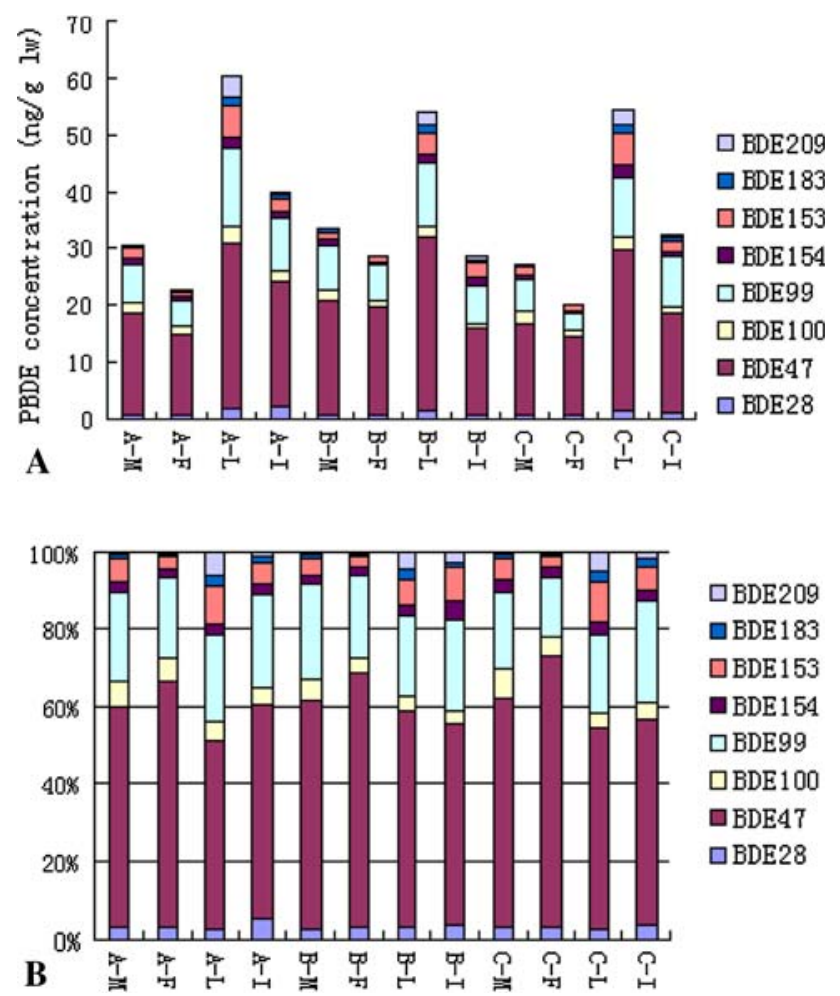

Fig. 1 PBDE concentration (a, ng/g lipid weight) and percentage distribution (b) in tissues of pigs
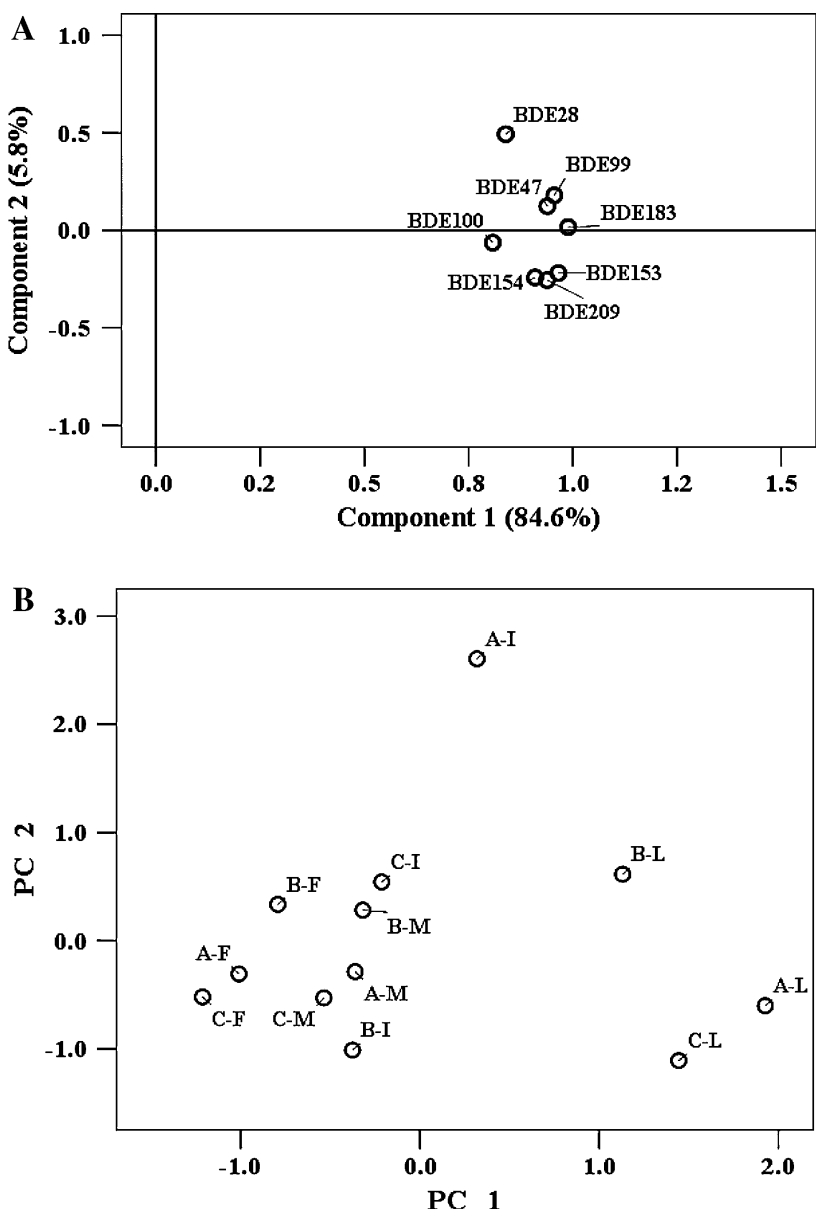

Fig. 2 Two-dimensional principal component loading plot (a) and score plot (b) obtained from the PBDEs data of pigs' tissues

determined by eigenvalues of over 1. As shown in Fig. 2a, two extracted PCs could explain $90.4 \%$ of the data variance. In the score plot of PCA (Fig. 2b), all the livers of pigs were assembled at the right of illustration, separated from other tissues, indicated the different accumulation ability of PBDEs between livers and other tissues of pigs raised in the village of South China.

As the similar tissue distribution of PBDEs in pigs (Fig. 1), we calculated the mean concentrations of 8 PBDE congeners in every tissue. To depict the tissue distribution of PBDEs in pigs, we calculated the mean concentration ratios of 8 PBDE congeners in muscle versus liver (M/L), fat versus liver $(\mathrm{F} / \mathrm{L})$ and intestine versus liver $(\mathrm{I} / \mathrm{L})$ (Fig. 3). All the ratios were lower than 1, which indicated the higher accumulation ability of PBDEs in liver than in other tissues. And the fat tissue had the lowest ratios in all PBDE congeners. Mörck et al. (2003) also shown that higher concentrations of BDE-209 were found in blood and blood-rich organs such as liver and the adipose tissue had the lowest concentrations in rat exposure of decabromodiphenyl ether. As illustrated in Fig. 3, the mean 


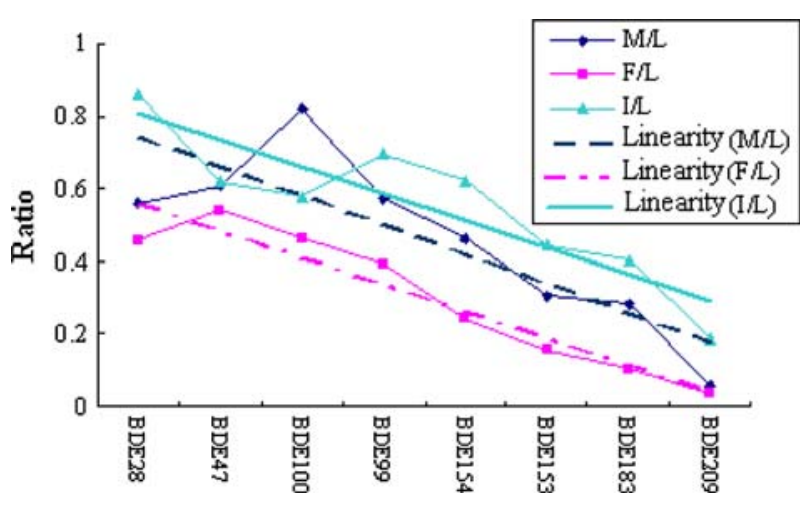

Fig. 3 Mean concentration ratio of 8 PBDE congeners obtained from muscle versus liver $(\mathrm{M} / \mathrm{L})$, fat versus liver $(\mathrm{F} / \mathrm{L})$ and intestine versus liver $(\mathrm{I} / \mathrm{L})$ in pigs

concentration ratios of $\mathrm{M} / \mathrm{L}, \mathrm{F} / \mathrm{L}$ and $\mathrm{I} / \mathrm{L}$ had the trend of decrease with increasing bromination degree of PBDE congeners. It maybe explained by three reasons: (1) as the blood-rich organ, the liver of pig had higher accumulation ability of PBDEs than other tissues; (2) the increase of octanol-water partition coefficients $\left(\mathrm{K}_{\mathrm{OW}} \mathrm{s}\right)$ with increasing bromination degree of PBDE congener would effect the passive diffusion of PBDEs in different tissues; (3) BDE209 had the lowest half-live, and the half-lives of PBDEs increased as the degree of bromination decreased from deca- to octa-BDEs in a rat decabromodiphenyl ether dietary exposure (Huwe and Smith 2007), and it would be the same in the pigs raised in the village of South China.

Acknowledgments This study was financially supported by the National Natural Scientific Foundation of China (No. 20707031), the National Basic Research Program of China (973 Program) (2003CB415005) and the Knowledge Innovation Program of Chinese Academy of Sciences(KZCX2-YW-420-3).

\section{References}

Bi XH, Qu WY, Sheng GY, Zhang WB, Mai BX, Chen DJ, Yu L, Fu JM (2006) Polybrominated diphenyl ethers in South China maternal and fetal blood and breast milk. Environ Pollut 144:1024-1030

D'Silva K, Fernandes A, Rose M (2004) Brominated organic micropollutants-igniting the flame retardant issue. Crit Rev Environ Sci Tech 34:141-207

Darnerud PO, Eriksen G, JÓhannesson T, Larsen P, Viluksela M (2001) Polybrominated diphenyl ethers: occurrence, dietary exposure and toxicology. Environ Health Persp 109:49-68

Dye JA, Venier M, Zhu LY, Ward CR, Hites RA, Birnbaum LS (2007) Elevated PBDE levels in pet cats: sentinels for humans? Environ Sci Technol 41:6350-6356

Hites RA (2004) Polybrominated diphenyl ethers in the environment and in people: a meta-analysis of concentrations. Environ Sci Technol 38:945-956

Huwe JK, Larsen GL (2005) Polychlorinated dioxins, furans, and biphenyls, and polybrominated diphenyl ethers in a u.s. meat market basket and estimates of dietary intake. Environ Sci Technol 39:5606-5611

Huwe JK, Smith DJ (2007) Accumulation, whole-body depletion, and debromination of decabromodiphenyl ether in male spraguedawley rats following dietary exposure. Environ Sci Technol 41:2371-2377

Law RJ, Allchin CR, de Boer J, Covaci A, Herzke D, Lepom P, Morris S, Tronczynski J, de Wit CA (2006) Levels and trends of brominated flame retardants in the European environment. Chemosphere 64:187-208

Li K, Fu S, Yang ZZ, Xu XB (2008) Composition, distribution and characterization of polybrominated diphenyl ethers (PBDEs) in the Soil in Taiyuan, China. Bull Environ Contam Toxicol 81:588-593

Luo XJ, Liu J, Luo Y, Zhang XL, Wu JP, Lin Z, Chen SJ, Mai BX, Yang ZY (2009) Polybrominated diphenyl ethers (PBDEs) in free-range domestic fowl from an e-waste recycling site in South China: Levels, profile and human dietary exposure. Environ Int $35: 253-258$

Mörck A, Hakk H, Örn U, Klasson WE (2003) Decabromodiphenyl ether in the rat: absorption, distribution, metabolism, and excretion. Drug Metab Dispos 31:900-907

Ohta S, Ishizuka D, Nishimura H, Nakao T, Aozasa O, Shimidzu Y, Ochiai F, Kida T, Nishi M, Miyata H (2002) Comparison of polybrominated diphenyl ethers in fish, vegetables, and meats and levels in human milk of nursing women in Japan. Chemosphere 46:689-696

Toms LML, Harden F, Paepke O, Hobson P, Ryan JJ, Mueller JF (2008) Higher accumulation of polybrominated diphenyl ethers in infants than in adults. Environ Sci Technol 42:7510-7515 